\title{
SENSITIVITAS FAKTOR EKONOMI MAKRO DAN MIKRO DALAM MEMPREDIKSI VOLATILITAS HARGA SAHAM PERUSAHAAN SEKTOR INDUSTRI FOOD \& BEVERAGES
}

\author{
Abdul Kohar ${ }^{1}$, Nurmala Ahmar ${ }^{2}$, dan Suratno ${ }^{3}$ \\ ${ }^{1}$ Universitas Pakuan, Bogor \\ ${ }^{2,3}$ Sekolah Pascasarjana Magister Akuntansi \\ Email: abdul.kohar@unpak.ac.id
}

\section{ARTICLE INFO \\ Article History: \\ Received 17 July 2018 \\ Revised 15 August 2018 \\ Accepted 31 August \\ 2018}

\section{JEL Classification}

E44

\section{Keywords:}

Inflation, Interest Rates,

Exchange Rate,

Asset Growth,

Growth Earnings, and

Stock Price Volatility

\section{ABSTRACT}

The movement of macroeconomic factors can be used to predict the movement of the stock price, but different researchers are using different macroeconomic factors because there is still no consensus among them which macroeconomic factors that have an influence on stock prices. This study aimed to analyze and test the impact of macroeconomics factors which consisting of inflation, interest rates, exchange rate, and microeconomy factors, consisting of asset growth, growth earnings and sales growth to the volatility of stock prices on food and beverages companies listed in Indonesia Stock Exchange between 2011 and 2015 period. The study measure the sensitivity of inflation and interest rates and stock price volatility by regressing each variable with a share price which will produce the sensitivity value of each variable. A total of 66 samples are tested by using the classic assumption as the precondition for regression analysis techniques (multiple regressions). The results showed that inflation is partially affect the stock price volatility, Indonesia Interest Rate (SBI) is partially effect on stock price volatility, and exchange rate and microeconomics are partially no effect on stock price volatility.

\section{PENDAHULUAN}

Volatilitas harga saham dipengaruhi oleh banyak faktor. Faktor yang mempengaruhi volatilitas harga saham dikategorikan dalam 2 kelompok, yaitu faktor makro dan mikro perusahaan. Faktor mikro meliputi pertumbuhan aset, pertumbuhan laba, pertumbuhan penjualan, arus kas, ROE, pengungkapan sukarela, pengungkapan informasi, dividen dan pertumbuhan perusahaan sedangkan faktor makro meliputi inflasi, suku bunga, dan nilai tukar.

Hykay (2015) dalam penelitiannya menyatakan bahwa inflasi berpengaruh signifikan terhadap harga saham. Begitu pula dengan Kurniawati dan Rizki (2014) yang menyatakan bahwa pertumbuhan laba berpengaruh terhadap harga saham. Sementara itu peneliti lain Paul et al. (2014), melakukan studi di Fiji Islands berpendapat 
Abdul Kohar: Sensitivitas Faktor...

terdapat dua faktor eksternal yang sangat berpengaruh terhadap harga saham yaitu inflasi dan nilai tukar. Hal senada, diteliti juga oleh Kabir et al. (2014) menyatakan bahwa harga saham di Malaysia dipengaruhi oleh inflasi, suku bunga serta nilai tukar. Sementara dari penelitian Sihaloho (2013) diperoleh hasil bahwa inflasi berpengaruh negatif signifikan terhadap harga saham. Jika inflasi meningkat maka harga saham akan menurun, begitu pula sebaliknya. Kemudian pada suku bunga diperoleh hasil bahwa suku bunga berpengaruh negatif signifikan terhadap harga saham. Jika suku bunga meningkat maka harga saham akan menurun pula, begitupun sebaliknya. Kandir (2008), memperkuat penelitian tersebut yaitu inflasi berpengaruh terhadap pergerakan harga saham.

Lain halnya dengan penelitian sebelumnya, Kewal (2012) menyatakan hal yang berbeda, hasil penelitiannya menemukan bahwa hanya kurs yang berpengaruh secara signifikan terhadap IHSG, sedangkan tingkat inflasi, suku bunga SBI dan pertumbuhan PDB tidak berpengaruh terhadap IHSG. Hal senada diungkapkan oleh Mok (2004), bahwasannya inflasi tidak mempengaruhi harga saham. Pada tahun yang sama 2004, Chiarella et al. mendapatkan hasil yang berbeda bahwa inflasi dan suku bunga berpengaruh terhadap harga saham. Pada tahun 2005, Ang dan Maddaloni melakukan penelitian dengan hasil yang memperkuat bahwa inflasi, suku bunga dan nilai tukar berpengaruh terhadap harga saham. Penelitian ini diperkuat oleh Permana (2009), yang membuktikan bahwa fundamental, suku bunga, inflasi mempunyai pengaruh secara signifikan terhadap perubahan harga saham perusahaan sedangkan secara parsial hanya variabel PBV mempunyai pengaruh secara signifikan.

Disamping faktor-faktor tersebut di atas harga saham dipengaruhi juga oleh faktor lain, Abbas et al. (2013) menambah dividen dalam penelitiannya namun penelitian yang dilakukan di Pakistan ini menghasilkan kesimpulan bahwa dividen tidak mempengaruhi harga saham hanya pertumbuhan laba dan ROE yang berpengaruh. Hasil ini diperkuat oleh Deitiana (2011), bahwa dividen tidak berpengaruh signifikan pada harga saham, begitu pun dengan pertumbuhan penjualan tidak berpengaruh terhadap harga saham. Sementara Rinati (2010) menambah variabel ROE dalam penelitannya namun hasilnya tidak berpengaruh, begitu juga halnya dengan pertumbuhan laba tidak berpengaruh signifikan, hanya pertumbuhan aset yang memiliki pengaruh signifikan.

Timbul et al. (2009) berpendapat hal yang sama terhadap penelitian Rinati bahwa ROE tidak berpengaruh terhadap harga saham, namun Timbul et al. menyimpulkan bahwa pertumbuhan laba dan pertumbuhan aset berpengaruh signifikan. Perbedaan penelitian mengenai ROE dilakukan oleh Kusumajaya (2011) dengan hasil ROE berpengaruh terhadap harga saham, begitu juga dengan pertumbuhan laba dan aset memiliki pengaruh signifikan. Meythi (2006) dan Board et al. (1989) meneliti variabel lain yang mempengaruhi harga saham yaitu arus kas, dengan hasil penelitian tidak berpengaruh terhadap harga saham. Ayu (2013) meneliti pengungkapan informasi terhadap harga saham dan berpengaruh signifikan.

Laju inflasi yang tinggi akan mendorong kenaikan harga bahan baku dan meningkatkan berbagai biaya operasi perusahaan, menyebabkan harga jual barang meningkat dan menurunkan daya beli masyarakat. Hal ini berdampak pada turunnya penjualan perusahaan, sehingga keuntungan dan kinerja keuangan perusahaan mengalami penurunan. Pada tingkat suku bunga yang tinggi tentu sangat memberatkan operasi perusahaan yang ingin melakukan investasi baru, terutama bagi perusahaan yang memiliki rasio pinjaman yang tinggi, karena terancam tidak mampu melunasi hutang-hutangnya, sehingga berdampak pada jatuhnya kinerja keuangan perusahaan. 
Kondisi nilai tukar rupiah terhadap dolar Amerika Serikat cenderung melemah selama enam tahun terakhir, akan tetapi Indeks Harga Saham Gabungan (IHSG) cenderung meningkat di setiap tahunnya. Hal ini tidak sesuai dengan teori yang dipaparkan bahwa melemahnya kurs akan menurunkan harga saham yang akan berakibat pada penurunan IHSG. Jika kurs melemah, maka harga saham akan menurun. Jika kurs menguat, maka harga saham akan meningkat. Pertumbuhan perusahaan merupakan salah satu indikator keberhasilan perusahaan dalam mempertahankan keberlangsungan operasional perusahaan, yang dapat tercermin dari pertumbuhan aset dan pertumbuhan laba perusahaan.

Penelitian ini bermaksud untuk menilai sejauh mana sensitivitas pergerakan faktor ekonomi makro dan faktor mikro dalam memprediksi volatilitas harga saham yaitu dengan menginvestigasi dan menguji secara empiris bahwa faktor ekonomi makro dan mikro berpengaruh terhadap volatilitas harga saham perusahaan.

\section{TELAAH TEORI DAN LITERATUR Teori Signalling}

Teori signalling dikemukakan oleh Ross (1977) dalam artikel yang berjudul "The Determination of Financial Structure: The Incentive - Signalling Approach". Teori tersebut menyatakan bahwa eksekutif perusahaan memiliki informasi yang lebih baik mengenai perusahaannya akan terdorong untuk menyampaikan informasi tersebut kepada calon investor agar harga sahamnya meningkat. Signalling Theory mendasarkan pada asumsi bahwa informasi yang diterima oleh masing-masing pihak tidak sama. Dengan kata lain, signalling theory berkaitan dengan adanya asimetri informasi antara manajemen perusahaan dengan pihak-pihak yang berkepentingan dengan informasi.

\section{Sensitivitas Inflasi, Suku Bunga, Nilai Tukar dan Pertumbuhan Perusahaaan}

Darmadji dan Fakhruddin (2006:116) mendefinisikan inflasi sebagai suatu kondisi ketika harga barang-barang pada umumnya menjadi lebih tinggi dari sebelumnya. Pada hakekatnya inflasi yang tinggi dapat memberikan dampak yang negatif ketika kenaikan harga jual produk perusahaan akibat naiknya biaya produksi tidak dapat diserap oleh pasar. Atau apabila peningkatan biaya produksi lebih tinggi dibandingkan peningkatan harga jual produk perusahaan maka hal ini akan mempengaruhi tingkat margin yang akan diperoleh perusahaan. Inflasi yang berkaitan dengan pasar modal adalah investasi yang berasal dari sektor moneter. Hal ini karena inflasi berkaitan langsung dengan tingkat suku bunga di pasar. Adapun besaran sensitivitas inflasi (beta inflasi) dalam penelitian ini diambil dengan cara meregres data inflasi selama periode amatan dengan harga saham food and baverages dalam periode amatan yang sama.

Suku bunga adalah biaya pinjaman atau harga yang dibayarkan untuk dana pinjaman tersebut (Miskhin, 2008: 4). Sedangkan menurut Sunariyah (2011) tingkat suku bunga adalah tingkat keuntungan yang didapat oleh investor atas investasi yang ditanamkan atau merupakan biaya yang harus keluarkan oleh perusahaan untuk menggunakan dana investor tersebut. Suku bunga ini penting untuk diperhitungkan karena rata-rata para investor yang selalu mengharapkan hasil investasi yang lebih besar. Dengan adanya perubahan suku bunga, tingkat pengembalian hasil berbagai sarana investasi akan mengalami perubahan. Sensitivitas suku bunga merupakan dampak dari perubahan suku bunga terhadap keuangan perusahan dalam periode tertentu. Adapun besaran sensitivitas inflasi (beta inflasi) dalam penelitian ini diambil dengan cara meregres data inflasi selama periode amatan dengan harga saham food and baverages dalam periode amatan yang sama. Sedangkan kurs valuta asing menurut Sukirno $(2013,397)$ 
didefinisikan sebagai "jumlah uang domestik yang dibutuhkan yaitu banyaknya rupiah yang dibutuhkan untuk memperoleh satu unit mata uang asing."

Selanjutnya pertumbuhan diartikan sebagai dampak atas arus dana perusahaan dari perubahan operasional yang disebabkan oleh pertumbuhan $(\Delta)$ atau penurunan volume usaha (Helfert, 2007). Pertumbuhan perusahaan sangat diharapkan oleh pihak internal maupun eksternal perusahaan, karena pertumbuhan yang baik memberi tanda bagi perkembangan perusahaan. Dari sudut pandang investor, pertumbuhan suatu perusahaan merupakan tanda perusahaan memiliki aspek yang menguntungkan, dan investor pun akan mengharapkan tingkat pengembalian (rate of return) dari investasi yang dilakukan menunjukkan perkembangan yang baik.

\section{Volatilitas Harga Saham}

Pergerakan naik atau turunnya harga saham di bursa efek merupakan volatilitas harga saham. Untuk mengukur risiko dari suatu saham dapat dilihat dari volatilitas harga saham tersebut. Volatilitas yang lebih besar menunjukkan kemungkinan terjadinya keuntungan atau kerugian yang lebih tinggi dalam jangka pendek. Harga dari saham yang mempunyai volatilitas tinggi dapat berubah sewaktu-waktu dan perubahannya sulit untuk diprediksi. Nilai volatilitas yang tinggi menunjukkan bahwa harga saham berubah (naik dan turun) dengan range yang sangat lebar. Sedangkan volatilitas dikatakan rendah jika harga saham jarang berubah atau cenderung konstan.

\section{PENGEMBANGAN HIPOTESIS}

Berdasarkan penelitian terdahulu yang dilakukan oleh Chiarella et al. (2004), Kandir (2008), Sihaloho (2013) serta Paul et al. (2014) menunjukkan bahwa inflasi mempunyai pengaruh negatif signifikan terhadap harga saham. Laju inflasi yang tinggi akan mendorong kenaikan harga bahan baku dan meningkatkan berbagai biaya operasi perusahaan, menyebabkan harga jual barang meningkat dan menurunkan daya beli masyarakat. Hal ini berdampak pada turunnya penjualan perusahaan, sehingga keuntungan dan kinerja keuangan perusahaan mengalami penurunan, yang pada akhirnya investor akan ragu untuk membeli saham perusahaan tersebut, hal ini menandakan volatilitas harga sahamnya rendah Berdasarkan hal tersebut di atas, maka dirumuskan hipotesis sebagai berikut:

\section{$\mathrm{H}_{1}$ : Sensitivitas inflasi berpengaruh signifikan negatif terhadap volatilitas harga saham pada perusahaan food and beverages yang terdaftar di BEI.}

Penelitian pengaruh suku bunga terhadap harga saham dilakukan oleh Granger et al. (1998), Watanapalachaikul (2003), Kabir et al. (2014), dan Hykaj (2015), hasil dari penelitian tersebut bahwa nilai tukar berpengaruh positif signifikan terhadap harga saham. Dengan adanya perubahan suku bunga, tingkat pengembalian hasil berbagai sarana investasi akan mengalami perubahan. Dengan menaikkan bunga SBI berarti bank dan lembaga keuangan lainnya akan terdorong untuk membeli SBI. Tentunya bunga yang tinggi ini berdampak pada alokasi dana investasi para investor. Berdasarkan uraian tersebut di atas, maka hipotesis selanjutnya adalah:

$\mathrm{H}_{2}$ : Sensitivitas Suku Bunga Indonesia (SBI) berpengaruh signifikan terhadap volatilitas harga saham pada perusahaan food and beverages yang terdaftar di BEI.

Penelitian yang dilakukan oleh Nirmalasari dan Soekarno (2012) menyatakan bahwa nilai tukar secara parsial memiliki pengaruh yang signifikan terhadap harga 
saham. Penelitian lain yang dilakukan oleh Darwati dan Santoso (2014) menunjukkan bahwa secara parsial nilai tukar berpengaruh terhadap harga saham. Hasil penelitian yang dilakukan oleh Achmad dan Ramli (2013) menyatakan bahwa secara parsial kurs USD/IDR memiliki pengaruh terhadap harga saham. Menguatnya kurs rupiah terhadap mata uang asing akan menurunkan biaya impor bahan baku untuk produksi, sehingga menguatnya kurs rupiah akan meningkatkan harga saham yang berdampak pada peningkatan Volatilitas Harga Saham. Berdasarkan hal tersebut, di atas dirumuskan hipotesis penelitian sebagai berikut:

H3: Sensitivitas nilai tukar memiliki pengaruh signifikan negatif terhadap volatilitas harga saham pada perusahaan food and beverages yang terdaftar di BEl.

Peningkatan aset yang diikuti peningkatan hasil operasi akan semakin menambah kepercayaan pihak luar terhadap perusahaan. Sriwadany (2006), Timbul et al. (2009), Rinati (2010), Kusumajaya (2011), menemukan bahwa pertumbuhan perusahaan mempunyai pengaruh langsung dan positif terhadap harga saham perusahaan, yang artinya bahwa infomasi tentang adanya pertumbuhan perusahaan direspon positif oleh investor, sehingga akan meningkatkan harga saham, maka dari itu penulis mencoba merumuskan hipotesis selanjutnya adalah:

$\mathrm{H}_{4}$ : Pertumbuhan aset berpengaruh signifikan terhadap volatilitas harga saham pada perusahaan food and beverages yang terdaftar di BEI.

Penelitian yang dilakukan oleh Permana (2009), Deitiana (2011), Abbas et al. (2013),Vika (2013) yang menyatakan keterkaitan antara pertumbuhan laba dan harga saham, mereka menyatakan bahwasanya pertumbuhan laba berpengaruh postitif terhadap harga saham, artinya bagi investor semakin besar kemampuan menghasilkan laba maka secara teoretis harga saham di pasar modal juga akan meningkat. Berdasarkan hal tersebut dirumuskan hipotesis sebagai berikut:

\section{$\mathrm{H}_{5}$ : Pertumbuhan laba berpengaruh signifikan terhadap volatilitas harga saham pada perusahaan food and beverages yang terdaftar di $\mathrm{BEI}$.}

Kusumajaya (2011) mengemukakan bahwa tingkat pertumbuhan perusahaan yang diukur dengan pertumbuhan penjualan memengaruhi nilai perusahaan atau harga saham perusahaan sebab pertumbuhan perusahaan menjadi tanda perkembangan perusahaan yang baik yang berdampak respon positif dari investor. Pertumbuhan penjualan diartikan sebagai kenaikan jumlah penjualan dari tahun ke tahun atau dari waktu ke waktu (Kennedy dkk., 2013). Berdasarkan hal tersebut, di atas dirumuskan hipotesis sebagai berikut:

$\mathrm{H}_{6}$ : Pertumbuhan penjualan berpengaruh signifikan terhadap volatilitas harga saham pada perusahaan food and beverages yang terdaftar di BEl.

\section{METODOLOGI PENELITIAN}

Populasi dan Teknik Penarikan Sampel

Dalam penelitian ini yang menjadi populasi adalah sebanyak 14 saham emiten sektor food and beverages yang terdaftar di Bursa Efek Indonesia (BEI). Metode sampling yang digunakan adalah metode sensus, semua anggota populasi dijadikan sampel penelitian Data yang digunakan adalah data sekunder yang merupakan data laporan keuangan dan harga saham yang dijadikan sampel dan tersedia di halaman website Bursa Efek Indonesia (www.idx.co.id), Yahoo Finance 
Abdul Kohar: Sensitivitas Faktor...

(www.finance.yahoo.com), www.bi.co.id dan www.bps.go.id.

\section{Operasionalisasi Variabel}

Dalam penelitian ini yang menjadi variabel independen adalah sensitivitas inflasi, sensitivitas suku bunga, sensitivitas nilai tikar, pertumbuhan aset, pertumbuhan laba dan pertumbuhan penjualan. Dalam penelitian ini yang menjadi variabel dependen adalah volatilitas harga saham.

Tabel 1. Operasionalisasi Variabel

\begin{tabular}{|c|c|c|c|c|}
\hline Variabel & Sub Variabel & Ukuran & Skala & Rujukan \\
\hline \multirow{3}{*}{$\begin{array}{l}\text { Faktor } \\
\text { Ekonomi } \\
\text { Makro }\end{array}$} & SensitivitasInflasi & $\begin{array}{l}\text { Harga Sekarang } \\
\text { Harga Tahun Dasar }\end{array}$ & \multirow{3}{*}{ Rasio } & \multirow{3}{*}{$\begin{array}{l}\text { Kabir et.al (2014), } \\
\text { Nirmalasari dan Soekarno } \\
\text { (2012, Sihaloha (2013), } \\
\text { Permana (2009), Ang et } \\
\text { al. (2005) }\end{array}$} \\
\hline & $\begin{array}{l}\text { Sensitivitas Suku } \\
\text { Bunga Indonesia }\end{array}$ & $\begin{array}{l}\text { Rata-rata BI RATE Selama } 1 \\
\text { Tahun }\end{array}$ & & \\
\hline & $\begin{array}{l}\text { SensitivitasNilai } \\
\text { Tukar }\end{array}$ & Kurs Tengah $=\frac{\text { Kurs Jual+Kurs Beli }}{2}$ & & \\
\hline \multirow{3}{*}{$\begin{array}{l}\text { Pertumbuhan } \\
\text { Perusahaan }\end{array}$} & Pertumbuhan Asset & $\begin{array}{l}\Delta \text { Total Aset } t \\
\text { Total Aset } \mathrm{t}-1\end{array}$ & \multirow{3}{*}{ Rasio } & \multirow{3}{*}{$\begin{array}{l}\text { Kusumajaya } \text { (2011), } \\
\text { Detiana (2011), Permana } \\
\text { (2009), Timbul et al. } \\
\text { (2009), } \\
\text { (2006) Sriwardany }\end{array}$} \\
\hline & Pertumbuhan Laba & $\frac{\Delta \text { Total Laba } t}{\text { Total Laba t-1 }}$ & & \\
\hline & $\begin{array}{l}\text { Pertumbuhan } \\
\text { Penjualan }\end{array}$ & $\frac{\text { St-St-1 }}{\text { St-1 }} \times 100 \%$ & & \\
\hline Harga Saham & $\begin{array}{l}\text { Harga Penutupan } \\
\text { Saham (Closing } \\
\text { Price) }\end{array}$ & $\begin{array}{l}\text { Rata-rata (mean) harga saham } \\
\text { selama periode tahun 2011- } \\
2015\end{array}$ & Rasio & $\begin{array}{ll}\begin{array}{l}\text { Kabir et al. } \\
\text { Sihaloha }\end{array} & \text { (2014), } \\
\text { Kusumajaya } & \text { (2011), } \\
\text { Permana (2009), Timbul } \\
\text { et al. (2009), Sriwardany } \\
\text { (2006), Ang et al. (2005) }\end{array}$ \\
\hline $\begin{array}{l}\text { Volatilitas } \\
\text { Harga Saham }\end{array}$ & $\begin{array}{l}\text { Harga Penutupan } \\
\text { Saham (Closing } \\
\text { Price) }\end{array}$ & $\begin{array}{l}\text { Rata-rata (mean) harga saham } \\
\text { (Standar Error ) selama periode } \\
\text { tahun } 2011-2015\end{array}$ & Rasio & $\begin{array}{l}\text { Hykaj (2015), Napitupulu } \\
\text { et al. (2013), Hugida dan } \\
\text { Sofian (2011),Anton } \\
\text { (2006), Jones et al. (1994) }\end{array}$ \\
\hline
\end{tabular}

Sumber : Jurnal Penelitian Sebelumnya.

\section{PENGUJIAN HIPOTESIS}

Sensitivitas Inflasi Berpengaruh Terhadap Volatilitas Harga Saham

Hipotesis yang pertama adalah sensitivitas inflasi berpengaruh signifikan negatif terhadap volatilitas harga saham pada perusahaan food and beverages yang terdaftar di BEl. Berdasarkan parameter statistik pada tabel 4.8 di atas, menunjukkan bahwa t hitung $>\mathrm{t}$ tabel $(-2.656>-2.001)$ dengan taraf signifikansi di bawah 0.05 yaitu 0.010 . Hal ini menunjukkan bahwa variabel sensitivitas inflasi secara parsial berpengaruh secara signifikan terhadap volatilitas harga saham. 
Sehingga hipotesis alternatif pertama yaitu $\mathrm{H}_{0}$ ditolak atau $\mathrm{H}_{1}$ diterima.

\section{Sensitivitas Suku Bunga Berpengaruh Terhadap Volatilitas Harga Saham}

Hipotesis yang kedua Sensitivitas Suku Bunga Indonesia (SBI) berpengaruh signifikan terhadap volatilitas harga saham pada perusahaan food and beverages yang terdaftar di BEl. Berdasarkan parameter statistik pada tabel 4.8 sebelumnya, menunjukkan bahwa $t$ hitung $>\mathrm{t}$ tabel $(4.543>2.001)$ dengan taraf signifikansi di bawah 0.05 yaitu 0.000 . Hal ini menunjukkan bahwa variabel sensitivitas suku bunga secara parsial berpengaruh secara signifikan terhadap volatilitas harga saham. Sehingga hipotesis alternatif kedua yaitu $\mathrm{H}_{0}$ ditolak atau $\mathrm{H}_{1}$ diterima.

\section{Sensitivitas Nilai Tukar Berpengaruh Terhadap Volatilitas Harga Saham}

Hipotesis yang ketiga sensitivitas nilai tukar memiliki pengaruh signifikan negatif terhadap volatilitas harga saham pada perusahaan food and beverages yang terdaftar di BEI. Berdasarkan parameter statistik pada tabel 4.8 sebelumnya, menunjukkan bahwa $t$ hitung $<\mathrm{t}$ tabel $(-0.997<-2.001)$ dengan taraf signifikansi di atas 0.05 yaitu 0.323 . Hal ini menunjukkan bahwa variabel sensitivitas nilai tukar secara parsial tidak berpengaruh secara signifikan terhadap volatilitas harga saham. Sehingga hipotesis alternatif ketiga yaitu $\mathrm{H}_{0}$ diterima atau $\mathrm{H}_{1}$ ditolak.

\section{Pertumbuhan Aset Berpengaruh Terhadap Volatilitas Harga Saham}

Hipotesis yang keempat pertumbuhan aset berpengaruh signifikan terhadap volatilitas harga saham pada perusahaan food and beverages yang terdaftar di BEI. Berdasarkan parameter statistik pada tabel 4.8 sebelumnya, menunjukkan bahwa t hitung $<\mathrm{t}$ tabel $(0,461<2.001)$ dengan taraf signifikansi di atas 0.05 yaitu 0.0 .647 . Hal ini menunjukkan bahwa variabel pertumbuhan aset secara parsial tidak berpengaruh secara signifikan terhadap volatilitas harga saham. Sehingga hipotesis alternatif keempat yaitu $\mathrm{H}_{0}$ diterima atau $\mathrm{H}_{1}$ ditolak.

\section{Pertumbuhan Laba Berpengaruh Terhadap Volatilitas Harga Saham}

Pertumbuhan laba berpengaruh signifikan terhadap volatilitas harga saham pada perusahaan food and beverages yang terdaftar di BEl. Berdasarkan parameter statistik pada tabel 4.8 sebelumnya, menunjukkan bahwa t hitung $<\mathrm{t}$ tabel $(0.950<$ 2.001) dengan taraf signifikansi di atas 0.05 yaitu 0.346. Hal ini menunjukkan bahwa variabel pertumbuhan laba secara parsial tidak berpengaruh secara signifikan terhadap volatilitas harga saham. Sehingga hipotesis alternatif kelima yaitu $\mathrm{H}_{0}$ diterima atau $\mathrm{H}_{1}$ ditolak.

\section{Pertumbuhan Penjualan Berpengaruh Terhadap Volatilitas Harga Saham}

Pertumbuhan Penjualan berpengaruh signifikan terhadap volatilitas harga saham pada perusahaan food and beverages yang terdaftar di BEl. Berdasarkan parameter statistik pada tabel 4.8 sebelumnya, menunjukkan bahwa t hitung < t tabel $(1.416<$ 2.001) dengan taraf signifikansi di atas 0.05 yaitu 0.346. Hal ini menunjukkan bahwa variabel pertumbuhan penjualan secara parsial tidak berpengaruh secara signifikan terhadap volatilitas harga saham. Sehingga hipotesis alternatif keenam yaitu $\mathrm{H}_{0}$ diterima atau $\mathrm{H}_{1}$ ditolak.

\section{PEMBAHASAN DAN INTERPRETASI \\ Pengaruh Sensitivitas Inflasi Terhadap Volatilitas Harga Saham \\ Inflasi berpengaruh negatif terhadap} volatilitas harga saham. Hal ini jelas menggambarkan bahwa laju inflasi yang tinggi akan mendorong kenaikan harga bahan baku dan meningkatkan berbagai biaya operasi perusahaan, menyebabkan harga jual per unit barang meningkat dan menurunkan daya beli 
Abdul Kohar: Sensitivitas Faktor...

masyarakat. Hal ini berdampak pada turunnya penjualan perusahaan, sehingga keuntungan dan kinerja keuangan perusahaan mengalami penurunan, yang pada akhirnya investor akan ragu untuk membeli saham perusahaan tersebut, hal ini menandakan volatilitas harga sahamnya rendah. Hasil penelitian ini konsisten dengan penelitian sebelumnya yaitu Sihaloho (2013), Permana (2009), dan Kandir (2008) yang hasil penelitiannya inflasi mempunyai pengaruh negatif signifikan terhadap harga saham. Begitu juga penelitian Thobarry (2009) yang menyatakan bahwa pengaruh negatif tingkat inflasi terhadap indeks harga saham sektor properti di BEI pada tahun 2000-2008. Hasil senada juga ditemukan pada penelitian oleh Paul, et al. (2014), Kabir, et al. (2014), Ang, et al. (2005), dan Chiarella, et al. (2004). Namun, penelitian Kewal, (2012) dan Mox (2004) terdapat hasil yang tidak konsisten dengan penelitian ini, mereka mengatakan bahwa inflasi tidak signifikan terhadap pergerakan harga saham. Dari hasil penelitian ini sejalan dengan literatur Tandelilin (2010, 343), bahwa peningkatan inflasi secara relatif merupakan sinyal negatif bagi pemodal di pasar modal.

Peningkatan inflasi akan menaikkan biaya produksi perusahaan. Kenaikan inflasi dapat menurunkan capital gain yang menyebabkan berkurangnya keuntungan yang diperoleh investor. Disisi perusahaan, terjadinya peningkatan inflasi yang peningkatannya tidak dapat dibebankan kepada konsumen dapat menurunkan tingkat pendapatan perusahaan. Hal ini berarti risiko yang akan dihadapi perusahaan akan lebih besar untuk tetap berinvestasi dalam bentuk saham, sehingga permintaan terhadap saham akan turun. Inflasi dapat menurunkan keuntungan suatu perusahaan sehingga sekuritas di pasar modal menjadi komoditi yang tidak menarik.

\section{Pengaruh Sensitivitas Suku Bunga Terhadap Volatilitas Harga Saham}

Suku bunga berpengaruh signifikan terhadap volatilitas harga saham pada perusahaan food and beverages yang terdaftar di BEl. Dengan hal seperti itu maka dapat disimpulkan bahwa suku bunga secara parsial berpengaruh terhadap volatilitas harga saham. Hanya Kewal, (2012) yang tidak konsisten dengan penelitian ini, sementara hasil dari penelitian lain konsisten dengan penelitian sebelumnya yang dilakukan oleh Sihaloho, (2013), Permana (2009), begitu juga dengan penelitian Hykay, (2015), Kabir, et al. (2014), Ang, et al. (2005), Chiarella, et al., Granger, et.al (1998). Penelitian Watanapalachaikul (2003) bahwasannya menyatakan suku bunga berpengaruh terhadap pergerakan harga saham, disamping faktor ekonomi lainnya yang dikaji seperti nilai tukar, harga pasar, harga pangan, EPR, CPI yang diteliti di negara Thailand pada tahun 1992-2001. Sejalan dengan teori yang disampaikan oleh Bodie and Marcus, 2006 bahwa bagi perusahaan, tingkat bunga yang tinggi mengurangi nilai sekarang dari arus kas masa depan, sehingga mengurangi daya tarik peluang sebuah investasi yang pada akhirnya investor akan menanamkan dananya pada saham yang secara langsung akan menaikkan volatilitas harga saham. Tingkat bunga yang rendah akan mendorong laju investasi dan konsumsi, sehingga karena ini tingkat bunga riil menjadi penentu kunci dari pengeluaran investasi bisnis.

\section{Pengaruh Sensitivitas Nilai Tukar Terhadap Volatilitas Harga Saham}

Nilai tukar berpengaruh signifikan terhadap volatilitas harga saham pada perusahaan food and beverages yang terdaftar di BEl. Namun hasil uji menyatakan bahwa variabel nilai tukar tidak berpengaruh secara signifikan terhadap volatilitas harga saham. Hal ini sejalan dengan penelitian sebelumnya yang dilakukan oleh Purnomo dan Widyawati (2013). Teknik analisis yang digunakan analisis regresi linear berganda yang diuji dengan uji $F$ dan uji t. Berdasarkan hasil uji $F$ diketahui 
bahwa nilai tukar, suku bunga, dan inflasi secara simultan berpengaruh terhadap return saham. Berdasarkan hasil uji t diketahui bahwa suku bunga secara parsial berpengaruh terhadap return saham, sedangkan nilai tukar dan inflasi secara parsial tidak berpengaruh terhadap return saham. Dari hasil uji $t$ juga dapat diketahui bahwa pengaruh dominan terhadap return saham ditunjukkan oleh variabel suku bunga. Hal yang sama pun dihasilkan dengan penelitian Raharjo (2009), bahwa nilai tukar tidak mempunyai pengaruh positif terhadap harga saham sebuah penelitian yang dilakukan pada perusahaan yang terdaftar di Bursa Efek Indonesia dari tahun 2007 - 2009. Penelitian ini diperkuat juga oleh Gupta dkk. (2000) yang mengadakan penelitian di Indonesia dengan judul The Causality Between Interest Rate, Exchange Rate and Stock Price in Emerging Market: The Case Of The Jakarta Stock Exchange. Data yang digunakan data periode 1993-1997 ini menyimpulkan bahwa tidak ada hubungan kausalitas antara tingkat bunga, nilai tukar, dan harga saham. Sehingga bahwa menguatnya kurs rupiah terhadap mata uang asing akan menurunkan biaya impor bahan baku dan akan menurunkan tingkat bunga yang berlaku, sehingga akan meningkatkan harga saham.

\section{Pengaruh Pertumbuhan Aset Terhadap Volatilitas Harga Saham}

Berdasarkan hasil penelitian yang telah dilakukan dengan menggunakan analisa regresi berganda dan dengan hasil hipotesis keempat yang menunjukkan bahwa pertumbuhan aset berpengaruh positif terhadap volatilitas harga saham pada perusahaan food and beverages yang terdaftar di BEI, namun jika didasarkan pada hasil uji bahwa variabel aset secara parsial tidak berpengaruh secara signifikan terhadap volatilitas harga saham. Hal ini sejalan dengan penelitian sebelumnya yang dilakukan oleh Kewal (2012), teknik analisis yang digunakan adalah regresi berganda. Hasil penelitian menemukan bahwa hanya kurs yang berpengaruh secara signifikan terhadap IHSG, sedangkan tingkat inflasi, suku bunga SBI dan pertumbuhan PDB tidak berpengaruh terhadap IHSG. Hal yang sama pun dihasilkan dengan penelitian Subiyantoro dan Andreani, 2003 bahwa aset tidak berpengaruh terhadap volatilitas harga saham, sebuah penelitian terhadap jasa perhotelan yang terdaftar pada pasar modal Indonesia dari tahun 1998-2001. Sementara peneliti lain tidak konsisten Kusumajaya, (2011), Rinati (2010), Permana (2009), Timbul, et al. (2009), dan Sriwardany (2006). Volatilitas harga saham tidak mengikuti pergerakan naik/turun aset perusahaan, hal ini disebabkan pertumbuhan asset pada perusahaan akan mencerminkan atau menandakan return atau keuntungan yang akan didapat oleh investor, maka investor akan senantiasa terus menginvestasikan pada saham tersebut sehingga saham tersebut akan lebih stabil.

\section{Pengaruh Pertumbuhan Laba Terhadap Volatilitas Harga Saham}

Berdasarkan hasil penelitian yang telah dilakukan dengan menggunakan analisa regresi berganda dan dengan hasil hipotesis kelima yang menunjukkan bahwa laba berpengaruh positif terhadap volatilitas harga saham pada perusahaan food and beverages yang terdaftar di BEI. Namun hasil uji menyatakan bahwa variabel laba tidak berpengaruh secara signifikan terhadap volatilitas harga saham. Hasil penelitian ini sejalan dengan penelitian sebelumnya yang dilakukan oleh Rinati pada tahun 2010, sampel yang digunakan adalah 11 perusahaan dari 45 perusahaan yang tercantum dalam indeks LQ45 selama periode 2004-2008, sehingga total sampel sebanyak 55 perusahaan. Ada empat variabel yang digunakan yaitu: harga saham sebagai dependent variable, sedangkan NPM, ROA dan ROE sebagai independent variable. Alat analisis yang digunakan adalah 
Abdul Kohar: Sensitivitas Faktor...

analisis regresi linier berganda. Pengambilan sampel pada penelitian ini dilakukan dengan cara tidak acak menggunakan purposive sampling. Hasil penelitian menunjukkan bahwa laba tidak berpengaruh terhadap pergerakan volatilitas harga saham. Dari penelitiian yang tidak konsisten dengan penelitian ini adalah Vika, (2013), Kusumajaya, Deitiana (2011), Permana, Timbul (2009), Sriwardany, (2006), begitu juga dengan penelitian dari Abbas, et.al. (2013) dan Watanapalachaikul et.al (2003). Pergerakan laba tidak diikuti oleh volatilitas harga saham. Hal ini terjadi investor hanya akan menanamkan sahamnya pada perusahaan yang cenderung stabil dalam menghasilkan laba, sehingga volatilitas pun akan cenderung stabil tidak mengalami naik turun secara signifikan.

\section{Pengaruh Pertumbuhan Penjualan Terhadap Volatilitas Harga Saham}

Berdasarkan hasil penelitian yang telah dilakukan dengan menggunakan analisa regresi berganda dan dengan hasil hipotesis keempat yang menunjukkan bahwa penjualan berpengaruh positif terhadap volatilitas harga saham pada perusahaan food and beverages yang terdaftar di BEl. Namun, hasil uji menyatakan bahwa variabel penjualan tidak berpengaruh secara signifikan terhadap volatilitas harga saham.

Hasil penelitian ini sejalan dengan penelitian sebelumnya yang dilakukan oleh Novitasari dan Widyawati (2015), sampel penelitian terdiri dari 18 perusahaan manufaktur yang termasuk dalam sektor industri dasar dan kimia dan sektor aneka industri yang terdaftar di Galeri Investasi Bursa Efek Indonesia yang dimulai dari tahun 2011 sampai tahun 2013. Metoda statistik yang digunakan dalam menentukan variabelvariabel yang dapat mempengaruhi harga saham adalah melalui teknik analisis regresi linier berganda. Hasil penelitian menunjukkan bahwa variabel yang berpengaruh positif terhadap harga saham adalah Net Profit
Margin (NPM). Sedangkan variabel independen lainnya yakni Return on Equity (ROE), Pertumbuhan Penjualan ( $\Delta \mathrm{St}$ ), dan Dividend Payout Ratio (DPR) tidak berpengaruh positif terhadap harga saham. Hal yang sama dengan penelitian yang dilakukan oleh Detiana (2011) yang menemukan bahwa variabel pertumbuhan penjualan tidak berpengaruh terhadap harga saham. Hal ini dapat terjadi karena perusahaan tidak mengevaluasi penjualan untuk mempengaruhi harga sahamnya. Investor hanya akan menanamkan sahamnya pada perusahaan yang cenderung stabil dalam menghasilkan penjualan, sehingga volatilitas pun akan cenderung stabil tidak mengalami naik turun secara signifikan.

\section{PENUTUP}

\section{Simpulan}

1. Sensitivitas inflasi secara parsial berpengaruh signifikan negatif terhadap volatilitas harga saham. Dengan hasil seperti itu menggambarkan inflasi berpengaruh negatif terhadap volatilitas harga saham. Hal tersebut menunjukkan bahwa laju inflasi yang tinggi akan mendorong kenaikan harga bahan baku dan meningkatkan berbagai biaya operasi perusahaan, menyebabkan harga jual barang meningkat dan menurunkan daya beli masyarakat. Hal ini berdampak pada turunnya penjualan perusahaan, sehingga keuntungan dan kinerja keuangan perusahaan mengalami penurunan, yang pada akhirnya investor akan ragu untuk membeli saham perusahaan tersebut, hal ini menandakan volatilitas harga sahamnya rendah.

2. Sensitivitas Suku Bunga Indonesia (SBI) secara parsial berpengaruh signifikan terhadap volatilitas harga saham. Hal tersebut memberi keyakinan bahwa suku bunga berpengaruh positif terhadap volatilitas harga saham. Tingkat bunga yang tinggi mengurangi nilai sekarang dari arus kas masa depan, sehingga mengurangi 
daya tarik peluang sebuah investasi yang pada akhirnya investor akan menanamkan dananya pada saham yang secara langsung akan menaikkan volatilitas harga saham. Tingkat bunga yang rendah akan mendorong laju investasi dan konsumsi, sehingga karena ini tingkat bunga riil menjadi penentu kunci dari pengeluaran investasi bisnis.

3. Sensitivitas nilai tukar secara parsial tidak berpengaruh signifikan terhadap volatilitas harga saham. Hal tersebut menggambarkan bahwa menguatnya kurs rupiah terhadap mata uang asing akan menurunkan biaya impor bahan baku dan akan menurunkan tingkat bunga yang berlaku, sehingga akan meningkatkan harga saham.

4. Pertumbuhan aset secara parsial tidak berpengaruh signifikan terhadap volatilitas harga saham. Hal tersebut menggambarkan bahwa pertunbuhan aset tidak memiliki dampak yang signifikan terhadap volatilitas harga saham dengan kata lain pertumbuhan aset pada perusahaan akan mencerminkan atau menandakan return atau keuntungan yang akan didapat oleh investor, maka investor akan senantiasa terus menginvestasikan pada saham tersebut sehingga saham tersebut akan lebih stabil.

5. Pertumbuhan laba secara parsial tidak berpengaruh signifikan terhadap volatilitas harga saham. Hal tersebut menggambarkan bahwa pertumbuhan laba tidak memiliki dampak yang signifikan terhadap volatilitas harga saham. Hal ini terjadi karena investor hanya akan menanamkan sahamnya pada perusahaan yang cenderung stabil dalam menghasilkan laba, sehingga volatilitas harga saham pun akan cenderung stabil tidak mengalami naik turun secara signifikan.

6. Pertumbuhan penjualan secara parsial tidak berpengaruh signifikan terhadap volatilitas harga saham. Hal ini dapat terjadi karena perusahaan tidak mengevaluasi penjualan untuk mempengaruhi harga sahamnya. investor hanya akan menanamkan sahamnya pada perusahaan yang cenderung stabil dalam menghasilkan penjualan, sehingga volatilitas pun akan cenderung stabil tidak mengalami naik turun secara signifikan.

\section{Keterbatasan Penelitian}

1. Penelitian ini hanya mengambil populasi dan sampel pada perusahaanperusahaan food and beverages di Bursa Efek Indonesia pada periode tahun 2011 sampai tahun 2015. Dengan pendeknya periode penelitian dan jumlah data yang terbatas tersebut, maka hasilnya pun terlihat kurang optimal.

2. Hasil penelitian tidak dapat menggambarkan situasi secara keseluruhan. Hal tersebut disebabkan jumlah perusahaan Food and Beverages yang terdaftar di Bursa Efek Indonesia pada periode penelitian jumlahnya sedikit. Selain dari pada itu, variabel yang digunakan dalam penelitian ini hanya mengggunakan dua variabel dari faktor internal dan eksternal perusahaan saja.

3. Pengujian autokerelasi menghasilkan tidak dapat disimpulkan.

\section{Riset Mendatang}

1. Untuk para akademisi dalam melihat sensitivitas faktor ekonomi makro dapat dilakukan dengan meregres terlebih dahulu data yang akan dilihat nilai sensitivitasnya, begitupun halnya dengan nilai volatilitas harga saham harus diregres terlebih dahulu.

2. Untuk para praktisi khususnya di sektor industri food and beverages bahwa faktor eksternal ternyata lebih besar berpengaruh terhadap banyaknya investasi yang akan ditanamkan pada sekuritas dipasar modal, ketimbang faktor internal perusahaan. Hal ini dapat 
Abdul Kohar: Sensitivitas Faktor...

terjadi karena faktor internal dapat dikontrol oleh perusahaan dibandingkan faktor eksternal yang sulit untuk diprediksi keterjadiannya. Sehingga, dalam hal akan berinvestasi faktor eksternal harus lebih banyak dikaji dan mendapat perhatian.

3. Untuk para peneliti lebih lanjut akan meneliti pengaruh makro dan mikro ekonomi terhadap volatilitas harga saham sektor lainnya sehingga dapat dipilih indeks harga saham sektor mana saja yang tahan terhadap kondisi makro dan mikro ekonomi yang tidak stabil dan sektor mana saja yang rentan terhadap tidak stabilnya kondisi makro dan mikro ekonomi, seperti misalnya kebijakan pemerintah dan kondisi ekonomi, sedangkan dari faktor mikro dapat dikaji arus kas perusahaan, pengungkapan informasi serta menggunakan alat uji E-Views.

\section{DAFTAR PUSTAKA}

Ang and Maddaloni. (2005). Frequently Used Variables Are GDP Growth Rate, Industrial Production Rate, Short-Term Interest Rate, Inflation Rate, Interest Rate Spread, Exchange Rate, Current Account Balance, Unemployment Rate, Fiscal Balance, Etc. Journal of Business Research.

Anton, A. (2006). Analisis Model Volatilitas Return Saham (Studi Kasus pada Saham LQ 45 di Bursa Efek Jakarta). Tesis, Program Pascasarjana Universitas Diponegoro.

Becker, Gary.S., (2007). Economic Theory. New Jersey: Transaction Publishers.

Bodie, Kane, Marcus. (2006). Investasi Buku 2. Terjemahan Zuliani Dalimunthe dan Budi Wibowo. Jakarta: Salemba Empat.

Darmadji, Tjiptono dan Fachruddin. (2006). Pasar Modal di Indonesia, Pendekatan
Tanya Jawab, Edisi 4, Jakarta: Penerbit Salemba Empat.

Deitiana. (2011). Pengaruh Rasio Keuangan, Pertumbuhan Penjualan Dan Deviden Terhadap Harga Saham. Jurnal Bisnis Dan Akuntansi Vol 13, No.1, Hal 57-66, April 2011.

Jones, Charles M, et al. (1994). Transactions, Volume, and Volatility. The Review of Financial Studies (1986-1998); Winter 1994; 7, 4.

Helfert, Erick A. 2000. Teknik Analisis Keuangan: Petunjuk Praktis untuk Mengelola dan Mengukur Kinerja Perusahaan. Dialih bahasakan oleh Herman Wibowo, Edisi Kedelapan, Jakarta : Erlangga.

Hugida, L., Sofian, S. (2011). Analisis FaktorFaktor Yang Mempengaruhi Volatilitas Harga Saham (Studi Pada Perusahaan Yang Terdaftar Dalam Indeks LQ45 Periode 2006-2009). Skripsi, Universitas Diponegoro.

Kristal Hykaj. (2015). Analysis Of Problematics Related To The Stock Market In Albania. European Scientific Journal. Vol 11. No.34.

Kurniawati, et al. (2014). Pengaruh Luas Pengungkapan Sukarela dalam Laporan Tahunan Terhadap Return dan Harga Saham, Skripsi. Fakultas Ekonomi, Universitas Airlangga.

Mishkin, Frederic S. (2008). Ekonomi Uang, Perbankan, dan Pasar Keuangan. Edisi Sembilan, jilid 2. Jakarta: Salemba Empat.

Napitupulu, V., Syahyunan, S. (2013). Pengaruh Return Saham, Volume Perdagangan Dan Volatilitas Harga Saham Terhadap Bid-Ask Spread Pada Perusahaan Yang Melakukan Stock Split Di Bursa Efek Indonesia. Jurnal Media Informasi Manajemen.

Natarsyah, S. (2000). Analisis Pengaruh Beberapa Faktor Fundamental Dan Resiko Sistematik Terhadap Harga Saham: Kasus Barang Konsumsi Yang 
Go - Public Di Pasar Modal Indonesia. Jurnal Ekonomi Bisnis Indonesia, vol. 15, no. 3: $294-1312$.

Noeriwan. (2013). Pengaruh Faktor Internal dan Eksternal Perusahaan Terhadap Nilai Perusahaan Pada Perusahaan Sektor Perbankan Yang Terdaftar Di BEI periode 2010-2012. Skripsi. Fakultas Ekonomi Universitas Negeri Semarang.

Paul, Muthucattu T, et al. (2011). A Study Of The Relation Between Inflation And Exchange Rates In The Fiji Islands: A Cointegration And Vector Error Correction Approach, The Journal of Developing Areas, Volume 48, No.4. University of the South Pacific, Fiji.

Permana, Y. (2009). Pengaruh Fundamental Keuangan, Tingkat Bunga Dan Tingkat Inflasi Terhadap Pergerakan Harga Saham. Jurnal Akuntansi. Universitas Gunadarma.

Purnomo, Dewi Y. (2008). Pengaruh Ukuran Perusahaan, Pertumbuhan Aktiva, Dan Profitabilitas Terhadap Harga Saham Pada Perusahaan Manufaktur Di BEI Periode 2001-2006. Tesis. Universitas Sebelas Maret Surakarta.

Rinati, I. (2010). Pengaruh Net Profit Margin (NPM), Return On Assets (ROA) Dan Return On Equity (ROE) Terhadap Harga Saham Pada Perusahaan Yang Tercantum Dalam Indeks LQ45, Skripsi. Fakultas Ekonomi, Universitas Gunadarma.

Ross, S.A, (1976). The Determination of Financial Structure: The IncentiveSignalling Approach, Bell Journal of economics, 8, 23-40.

Sihaloho, Lira. (2013). Pengaruh Inflasi, Suku Bunga dan Book Value (BV) terhadap Harga Saham Perusahaan Indeks LQ 45 yang Terdaftar Di Bursa Efek Indonesia (BEI). Skripsi. Fakultas Ekonomi Universitas Negeri Semarang.
Saidi. (2004). Faktor-faktor yang Mempengaruhi Struktur Modal pada Perusahaan Manufaktur Go Public di BEJ Tahun 1997-2002. Jurnal Bisnis dan Ekonomi. Vol. 11, No.1, Maret 2004.

Humayun, S, et al. (2014). Stock Price Evidence from Malaysia. The Journal of Developing Areas. Volume 48. No.3.

Subiyantoro, E., dan Andreani, F. (2003). Analisis Faktor-Faktor Yang Mempengaruhi Harga Saham. Jurnal Ekonomi Manajemen, Vol.5, No.2 September 2003.

Suhardi, Deddy A. (2007). Pergerakan Harga Saham Sektor Properti Bursa Efek Jakarta Berdasarkan Kondisi Profitabilitas, Suku Bunga Dan Beta Saham. Jurnal Organisasi dan Manajemen Vol. 3 No. 2 Hal 89-103. Jakarta: Universitas Terbuka.

Sunariyah. (2011). Pengantar Pengetahuan Pasar Modal. Edisi 5. Yogyakarta: UPP STIM YKPN.

Kewal, Suramaya S. (2012). Pengaruh Inflasi, Suku Bunga, Kurs, Dan Pertumbuhan PDB Terhadap Indeks Harga Saham Gabungan. Jurnal Economia, Volume 8, Nomor 1, April 2012.

Suratno. (2017). Capital Struktures: Towards Realizing Economic Growth. Medwell Journal. The Social Sciences 12 (3): 467-472. Universitas Pancasila. Jakarta Selatan.

Shafqat, S, et al. (2013). Reexamining The Relationship of Earnings And EquityWith Share Price: A Study Of Company Specific And Uncontrollable Dynamics In Pakistan, Journals Sci, Int(Lahore), 25(4), 927-935, B. Z. University, Multan-Pakistan.

Tandelilin, E. (2010). Portofolio dan Investasi: Teori dan Aplikasi. Edisi 1. Yogyakarta: Kanisius.

Thobarry, A. A. (2009). Analisis Pengaruh Nilai Tukar, Suku Bunga, Laju Inflasi dan 
Abdul Kohar: Sensitivitas Faktor...

Pertumbuhan GDP Terhadap Indeks Harga Saham Sektor Properti (Kajian Empiris pada Bursa Efek Indonesia Periode Pengamatan Tahun 20002008). Tesis, Universitas Diponegoro.

Saut, U., et al. (2009). Analisis Pengaruh EVA, ROA, ROE dan Persentase Kepemilikan Modal Saham Asing terhadap Harga Saham Perbankan Di BEl. Artikel, Universitas Gunadarma.

Vika, D. (2013). Analisis Pengaruh Faktor Ekonomi Makro dan Pertumbuhan Perusahaan Terhadap Harga Saham. Skripsi Fakultas Ekonimika dan Bisnis Universitas Diponogoro.
Witha, Ni Made D. (2012). Pengaruh Faktor Ekonomi Makro Dan Kinerja Keuangan Terhadap Nilai Perusahaan Manufaktur Di Bursa Efek Indonesia, Fakultas Ekonomi, E-Journal Ekonomi dan Bisnis, Universitas Udayana.

Zulfa, N. A. (2015). Analisis Estimasi Volatilitas Indeks Harga saham Menggunakan Harga Tertinggi, Terendah, Pembukaan, Dan Penutupan (Studi pada Indeks Saham Sektoral di Bursa Efek Indonesia Periode 4 Maret 2013-4 Maret 2015). Skripsi, Universitas Negeri Semarang.

\section{LAMPIRAN}

Tabel 2. Asumsi Klasik, Uji F dan Uji t One-Sample Kolmogorov-Smirnov Test

\begin{tabular}{l|l|r}
\hline \multicolumn{2}{l|}{} & $\begin{array}{c}\text { Unstandardize } \\
\text { d Residual }\end{array}$ \\
\hline $\mathrm{N}$ & Mean & 66 \\
\cline { 2 - 3 } Normal Parameters $^{\mathrm{a}, \mathrm{b}}$ & Std. Deviation &, 0000000 \\
\hline \multirow{2}{*}{$\begin{array}{l}\text { Most Extreme } \\
\text { Differences }\end{array}$} & Absolute &, 096 \\
\cline { 2 - 3 } & Positive &, 096 \\
\cline { 2 - 3 } & Negative &,- 068 \\
\hline \multicolumn{2}{l|}{ Test Statistic } &, 096 \\
\hline Asymp. Sig. (2-tailed) & &, $200^{\mathrm{c}, \mathrm{d}}$ \\
\hline
\end{tabular}

a. Test distribution is Normal.

b. Calculated from data.

c. Lilliefors Significance Correction.

d. This is a lower bound of the true significance.

Tabel 3. Multikolinearitas

\section{Coefficients ${ }^{\mathrm{a}}$}

\begin{tabular}{|c|c|c|c|c|c|}
\hline \multirow{2}{*}{\multicolumn{2}{|c|}{ Model }} & \multirow[b]{2}{*}{$\mathrm{t}$} & \multirow[b]{2}{*}{ Sig. } & \multicolumn{2}{|c|}{ Collinearity Statistics } \\
\hline & & & & \multirow{2}{*}{ Tolerance } & \multirow[t]{2}{*}{ VIF } \\
\hline \multirow[t]{7}{*}{1} & $\begin{array}{c}\text { (Constant } \\
\text { ) }\end{array}$ & $-1,675$ & 099 & & \\
\hline & SINF & $-2,656$ & 010 & 789 & 1,267 \\
\hline & SSBI & 4,543 & 000 & 862 & 1,160 \\
\hline & SNTK &,- 997 & ,323 & 894 & 1,119 \\
\hline & GA & 461 & 647 & 927 & 1,079 \\
\hline & GP &,- 950 & ,346 & ,805 & 1,242 \\
\hline & GS & 1,416 & 162 & ,856 & 1,168 \\
\hline
\end{tabular}


a. Dependent Variable: Volatilitas SHM

Tabel 4. Uji t

\begin{tabular}{|c|c|c|c|c|c|c|}
\hline & & \multicolumn{5}{|c|}{ Coefficients $^{a}$} \\
\hline & & \multicolumn{2}{|c|}{ Unstandardized Coefficients } & \multirow{2}{*}{$\begin{array}{c}\text { Standardized } \\
\text { Coefficients } \\
\text { Beta }\end{array}$} & \multirow[b]{2}{*}{$\mathrm{t}$} & \multirow[b]{2}{*}{ Sig. } \\
\hline \multicolumn{2}{|c|}{ Model } & $\mathrm{B}$ & Std. Error & & & \\
\hline \multirow[t]{7}{*}{1} & (Constant) & ,392 & ,031 & & 12,578 & ,000 \\
\hline & BINF &,- 116 & ,091 &,- 173 & $-1,282$ & ,205 \\
\hline & BSBI &, 052 &, 063 & ,106 & 824 & ,413 \\
\hline & BNTK &,- 024 & ,047 &,- 066 &,- 521 & ,604 \\
\hline & GA &,- 094 &, 056 &,- 207 & $-1,667$ & ,101 \\
\hline & GP &,- 033 & ,031 &,- 144 & $-1,080$ & ,284 \\
\hline & GS &,- 022 & ,024 &,- 118 &,- 908 & ,368 \\
\hline
\end{tabular}

a. Dependent Variable: Abs_res

Tabel 5. Uji Autokorelasi

Model Summary

\begin{tabular}{l|r|r|r|r|r}
\hline Model & $\mathrm{R}$ & R Square & $\begin{array}{c}\text { Adjusted R } \\
\text { Square }\end{array}$ & $\begin{array}{c}\text { Std. Error of } \\
\text { the Estimate }\end{array}$ & $\begin{array}{c}\text { Durbin- } \\
\text { Watson }\end{array}$ \\
\hline 1 &, $565^{\mathrm{a}}$ &, 319 &, 250 &, 43754 & 2,546 \\
\hline
\end{tabular}

a. Predictors: (Constant), GS, GA, SNTK, SSBI, GP, SINF

b. Dependent Variable: Volatilitas SHM

Tabel 6. Uji F

ANOVA $^{a}$

\begin{tabular}{l|l|r|r|r|r|r}
\hline \multicolumn{2}{l|}{ Model } & $\begin{array}{c}\text { Sum of } \\
\text { Squares }\end{array}$ & df & Mean Square & F & Sig. \\
\hline \multirow{2}{*}{1} & Regression & 5,302 & 6 &, 884 & 4,616 &, $001^{\text {b }}$ \\
\cline { 2 - 7 } & Residual & 11,295 & 59 &, 191 & & \\
\cline { 2 - 7 } & Total & 16,597 & 65 & & & \\
\hline
\end{tabular}

a. Dependent Variable: Volatilitas SHM

b. Predictors: (Constant), GS, GA, SNTK, SSBI, GP, SINF 
